\title{
Penerapan Pendidikan Matematika Dasar Menggunakan Pendekatan Realistik untuk Anak Usia Dini di Kelurahan Kampung Lapai
}

\author{
Lilis Harianti Hasibuan ${ }^{1)}$ Darvi Mailisa Putri ${ }^{2)}$ Miftahul Jannah ${ }^{3)}$ \\ Matematika, Fakultas Saintek, Universitas Islam Negeri Imam Bonjol Padang, Indonesia ${ }^{1), 2), 3)}$ \\ Pos-el:lilisharianti@uinib.ac.id ${ }^{1)}$;darvimailisa@uinib.ac.id ${ }^{2)} ;$ miftahuljannah@uinib.ac.id ${ }^{3)}$
}

\begin{tabular}{|l|l|l|}
\hline Dikirim: 15,01, 2020 & Direvisi: 04,02, 2020 & Diterbitkan: 28,02, 2020 \\
\hline
\end{tabular}

\begin{abstract}
Abstrak
Penyuluhan yang berjudul Penerapan Pendidikan Matematika Dasar Menggunakan Pendekatan Realistik untuk Anak Usia Dini di Kelurahan Kampung Lapai mengajukan masalah bagaimana penerapan Pendidikan Matematika Dasar pada anak usia dini. Untuk mengatasi masalah di atas penulis mengajukan konsep agar anak usia dini bisa memahami pelajaran matematika dengan mudah dan menyenangkan. Pada anak usia dini perkembangan kemampuan matematis dimulai sejak kecil, dan berlanjut saat anak-anak berkembang secara mental, fisik, dan sosial, yang berpengaruh secara langsung terhadap perkembangan dan kemampuan mereka. Pendidikan matematika dapat diberikan kepada anak sejak usia 0-6 tahun. Anak pada usia 0-6 tahun perlu mendapaat perhatian khusus karena pada usis inilah kesiapan mental dan emosional anak mulai dibentuk. Pendidikan anak usia dini (PAUD) ikut serta dalam menjamin mutu pendidikan dan kebrhasilan akademis secara signifikan dipengaruhi oleh kualitas masukan pendidikan yaitu kesiapan mental dan emosional anak memasuki sekolah dasar. Metode dari penelitian ini adalah penelitian deskriptif. Penelitian ini hanya mendeskripsikan pembelajaran menggunakan pendekatan realistik pada anak usia dini dalam belajar matematika dasar. Adapun sampel yang akan menjadi responden pada pengabdian ini adalah siswa PAUD Amanah dengan menggunakan analisis inferensial produc moment. Berdasarkan perhitungan diperoleh $t_{\text {hitung }}$ lebih besar dari $t_{\text {tabel }}(5,231>1,694)$. Artinya terdapat hubungan positif yang tinggi atau kuat antara pendekatan realistik dan pemahaman matematika dasar pada anak usia dini.
\end{abstract}

Kata Kunci: matematika dasar, pendekatan realistik, pendidikan anak usia dini

\begin{abstract}
Counseling entitled Application of Basic Mathematics Education Using a Realistic Approach for Early Childhood in Kelurahan Kampung Alai raised the issue of how to apply Basic Mathematics Education to early childhood. To overcome the problem above, the writer proposes a concept so that early childhood can understand mathematics with ease and fun. In early childhood the development of mathematical abilities starts from childhood, and continues when children develop mentally, physically, and socially, which directly affects their development and abilities. Mathematics education can be given to children from the age of 0-6 years. Children at the age of 0-6 years need to get special attention because it is in this context that children's mental and emotional readiness begins to form. Early childhood education (PAUD) participates in ensuring the quality of education and academic success is significantly influenced by the quality of educational input namely the mental and emotional readiness of children entering primary school. The method of this research is descriptive research. This study only describes learning using a realistic approach to early childhood learning basic mathematics. The sample that will be respondents in this service are Amanah PAUD students using inferential produc moment analysis. Based on the calculation, tcount is greater than ttable
\end{abstract}


(5.231> 1.694). This means that there is a high or strong positive relationship between a realistic approach and basic mathematics understanding in early childhood.

Keywords:basical mathematics, realystic method, early childhood mathematics education

\section{PENDAHULUAN}

Rendahnya mutu pendidikan masih terlekat kepada bangsa Indonesia. Hal ini dapat diminimalkan dengan mengoptimalkan pendidikan pada anak sejak dini. Terutama pendidikan matematika. Banyak masyarakat menganggap bahwa matematika adalah mata pelajaran yang sulit untuk dimengerti, dan aplikasinya yang tidak terlalu jelas pada kehidupan sehari-hari. Tapi pendapat tersebut tidaklah benar, mengingat bahwa matematika sebagai ratu dan raja bagi cabang ilmu pengetahuan. Matematika dianggap sebagai ratu dan raja bagi ilmu pengetahuan karena matematika banyak digunakan pada bidang ilmu pengetahuan yang lain. Matematika dapat diberikan pada anak usia dini sejak usia 0-6 tahun. Anak mulai belajar dan beradaptasi dengan lingkungannya sejak bayi. Hal ini dikarenakan pertumbuhan otak bayi dibentuk pada usia 0-6 tahun. Oleh sebab itu asupan nutrisi yang cukup juga harus diperhatikan. Menurut Mujib dan Mudjakir (2001:70) "Di dalam otak terdapat neurologi sekitar 50\% kapasitas kecerdasan manusia terjadi pada usia 4 tahun, 80\% terjadi ketika usia $80 \%$, dan 100\% ketika anak mencapai usia 8-18 tahun". Itulah sebabnya, mengapa masa anak-anak dinamakan masa keemasan. Sebab, setelah masa perkembangan ini lewat, berapapun kapasitas kecerdasan yang dicapai oleh masing-masing individu, tidak akan meningkat lagi. Bagi yang memiliki anak, tentu tidak ingin melewatkan masa keemasan ini.

Pada dasarnya setiap anak dianugerahi kecerdasan matematika dasar. Gardner (1999:12) mendefiisikan kecerdasan matematis dasar sebagai kemampuan penalaran ilmiah, perhitungan secara matematis, berfikir logis, penalaran induktif dan deduktif, dan ketajaman pola-pola abstrak serta hubungan-hubungan. Dapat diartikan juga sebagai kemampuan menyelesaikan masalah yang berkaitan dengan kebutuhan matematika sebagai solusinya. Anak dengan kemampuan ini akan senang dengan rumus dan pola-pola abstrak. Tidak hanya pada bilangan matematika, tetapi juga meningkat pada kegiatan yang bersifat analitis dan konseptual. Menurut Gardner (1999:24) ada kaitan antara kecerdasan matematik dan kecerdasan linguistik. Pada kemampuan matematika, anak menganalisa atau menjabarkan alasan logis, serta kemampuan mengkonstruksi solusi dari persoalan yang timbul. Kecerdasan linguistik diperlukan untuk menjabarkannya dalam bentuk bahasa. Oleh sebab itu masalah yang diajukan adalah bagaimana merangsang kecerdasan matematis logis anak sejak usia dini dan bagaimana kita menanamkan konsep matematika logis sejak dini dalam kehidupan sehari-hari.

\section{METODE}

Penelitian ini dilaksanakan di PAUD Amanah di kelurahan Kampung Lapai Kecamatan Nanggalo Kota Padang. Alasan penulis memilih lokasi penelitian tersebut karena sepengetahuan penulis belum ada yang membahas masalah pengaruh penerapan pendekatan realistik terhadap pendidikan matematika dasar di PAUD Amanah Kampung Lapai 
Kecamatan Nanggalo Kota Padang. Pelaksanaan pengabdianini dimulai bulan Oktober2019 sampai dengan Desember.

Metode dari penelitian ini adalah penelitian deskriptif. Penelitian ini hanya mendeskripsikan pembelajaran menggunakan pendekatan realistik pada anak usia dini dalam belajar matematika dasar.

Populasi adalah keseluruhan objek yang akan dijadikan sebagai subjek penelitian yang memiliki karakteristik tertentu. Arikunto (2010) menyebutkan "Populasi adalah keseluruhan objek penelitian". Adapun yang menjadi populasi dalam penelitian ini adalah seluruh siswa PAUD Amanah di kelurahan kampung alai, kecamatan Nanggalo.

Sampel adalah sebagian yang diambil dari populasi. Hal ini sesuai dengan pendapat Arikunto (2010) mengatakan bahwa "Sampel adalah sebagian atau wakil dari populasi yang diteliti”. Mengingat jumlah populasi yang cukup banyak dan berkelompok maka penulis mengambil sebagian dari populasi untuk dijadikan sampel.

Teknik pengambilan sampel dari populasi dilakukan dengan teknik sampling kelompok (clustersampling) Menurut Arikunto (2007), "cluster sampling digunakan oleh peneliti apabila di dalam populasi terdapat kelompok-kelompok yang mempunyai ciri sendirisendiri". Dan yang menjadi sampel penelitian ini adalah siswa PAUD yang berumur 4-6 tahun

Pengumpulan data merupakan langkah yang amat penting dalam metode ilmiah, karena pada umumnya data yang dikumpulkan digunakan untuk menguji hipotesis yang telah dirumuskan. Pengumpulan data dapat dilakukan dalam berbagai setting, berbagai sumber, dan berbagai cara. Data yang akan dikumpulkan adalah berupa fakta, pendapat dan kemampuan. Sugiyono mengatakan, "Teknik pengumpulan data dapat dilakukan dengan interview (wawancara), kuesioner (angket), observasi (pengamatan) dan gabungan ketiganya" (Sugiyono, 2007). Untuk memperoleh data yang dibutuhkan, peneliti menggunakan beberapa instrumen sebagai alat pengumpul data:

1. Tes

Tes digunakan untuk memperoleh data tentang keaktifan belajar matematika siswa anak PAUD Amanah pada matematika dasar. Tes ini dibagi dalam satu tahap, yaitu tes setelah diberikan pendekatan realistik. Dalam hal tertentu untuk tes yang telah disusun sesuai dengan kurikulum (materi dan tujuan) agar memenuhi validitas dapat pula diminta bantuan ahli bidang studi untuk menotasikan apakah konsep materi yang diajukan telah memadai sebagai sampel tes. Tes yang diberikan pada siswa sebanyak 20 butir berbentuk pilihan berganda. Adapun kisi-kisi instrumen variabel penguasaan matematika dasar dapat dilihat pada tabel berikut:

Tabel 1: Kisi-Kisi Instrumen Pemahaman

Matematika Dasar PAUD Amanah

\begin{tabular}{|l|l|l|l|}
\hline No & \multicolumn{1}{|c|}{ Indikator } & $\begin{array}{c}\text { Nomor } \\
\text { Soal }\end{array}$ & $\begin{array}{c}\text { Banyak } \\
\text { Soal }\end{array}$ \\
\hline 1. & Mengembangkan kepekaan bilangan & $1,2,3,4$ & 4 \\
\hline
\end{tabular}


Volume 3, Nomor 1, Februari 2020

\begin{tabular}{|c|c|c|c|}
\hline 2. & Menyatakan lawan bilangan & $5,6,7$ & 3 \\
\hline 3. & $\begin{array}{l}\text { Mampu menyortir, menggolongkan, } \\
\text { membandingkan,dan menyusun benda-benda } \\
\text { menurut bentuk, jumlah, dan sifat-sifat lain. }\end{array}$ & $8,9,10$ & 3 \\
\hline 4. & $\begin{array}{lll}\text { Mengidentifikasi dan } & \text { menciptakan } & \text { pola } \\
\text { dihubungkn dengan penggolongan } & \text { atau } \\
\text { penyortiran } & & \end{array}$ & $11,12,13$ & 3 \\
\hline 5. & $\begin{array}{l}\text { Membangun konsep geometri pada anak } \\
\text { dimulai dengan mengidentifikasi bentuk- } \\
\text { bentuk, menyelidiki bangunan dan memisahkan } \\
\text { gambar-gambar biasa seperti segi empat, } \\
\text { lingkaran, segitiga. }\end{array}$ & $14,15,16$ & 3 \\
\hline 6. & $\begin{array}{l}\text { Mengukur, menimbang, dan membandingkan } \\
\text { ukuran benda-benda }\end{array}$ & $\begin{array}{l}17,18,19, \\
20\end{array}$ & 4 \\
\hline \multicolumn{3}{|c|}{ Jumlah } & 20 \\
\hline
\end{tabular}

\section{Angket}

Angket atau kuesioner merupakan cara pengumpulan data secara tidak langsung. Angket berisi pertanyaan atau pernyataan yang harus dijawab atau direspon oleh responden. Angket diberikan kepada anak didik setelah pembelajaran selesai dilaksanakan untuk mengetahui respon siswa terhadap proses pembelajaran yang telah berlangsung. Angket yang diberikan terdiri dari 20 butir pertanyaan dengan dengan 5 alternatif pilihan yaitu:

$\begin{array}{lc}\text { Sangat setuju } & : 5 \\ \text { Setuju } & : 4 \\ \text { Ragu-ragu } & : 3 \\ \text { Tidak Setuju } & : 2 \\ \text { Sangat Tidak Setuju } & : 1\end{array}$

Tabel 2: Kisi-Kisi Angket Respon Siswa PAUD Amanah

\begin{tabular}{|l|l|l|l|}
\hline No. & Respon Siswa & Nomor Butir Angket & Jumlah \\
\hline 1. & Membandingkan, menyusun dan & $1,2,3$ & 3 \\
\hline menata & Mengidentifikasi dan menciptakan & $4,5,6$ & 3 \\
\hline
\end{tabular}




\begin{tabular}{|l|l|l|l|}
\hline & pola & & \\
\hline 3. & $\begin{array}{l}\text { Mengenal, menggambar bentuk } \\
\text { benda }\end{array}$ & $7,8,9$ & 3 \\
\hline 4. & $\begin{array}{l}\text { Memciptakan pola hubungan } \\
\text { benda }\end{array}$ & $10,11,12$ & 3 \\
\hline 5. & $\begin{array}{l}\text { Membangun konsep geometri } \\
\text { 6. membandingkan }\end{array}$ & $\begin{array}{l}\text { Mengukur, 16,17,18 } \\
\text { ukuran benda }\end{array}$ & 3 \\
\hline 7. & $\begin{array}{l}\text { Mengumpulkan informasi tentang } \\
\text { dirinya sendiri dan lingkungan }\end{array}$ & 39,20 & 2 \\
\hline Jumlah & 20 \\
\hline
\end{tabular}

\section{Dokumentasi}

Dokumentasi digunakan untuk memperkuat data yang diperoleh dengan mencatat atau mengabadikan kegiatan berupa foto atau melihat catatan-catatan (arsip-arsip) yang dilakukan dalam penelitian.Dokumen-dokumen tersebut antara lain berupa arsip perencanaan pembelajarandan hasil pekerjaan siswa yang dapat memberi informasi data serta dokumen berupa foto yang menggambarkan situasi pembelajaran matematika pada anak PAUD Amanah kelurahan lapai, kecamatan Nanggalo Kota Padang.

\section{HASIL DAN PEMBAHASAN}

Data yang diperoleh melalui hasil penelitian di lapangan terhadap 35 responden anak PAUD Amanah kelurahan Lapai Kecamatan Nanggalo maka data tersebut dianalisis untuk memberikan gambaran tentang hubungan hasil belajar pendidikan matematika dasar pada anak paud dengan pendekatan realistik.

Teknik ini dipergunakan untuk melihat apakah ada hubungan yang signifikan antara pendekatan realistik yang digunakan guru kepada anak PAUD Amanah di kelurahan Lapai Kecamatan Nanggalo dalam mengenalkan matematika dasar. Adapun rumus yang digunakan adalah rumus " $r$ " Product Moment yaitu:

$$
r_{x y}=\frac{n \sum X Y-\left(\sum X\right)\left(\sum Y\right)}{\sqrt{\left\{n \sum X^{2}-\left(\sum X\right)^{2}\right\}\left\{n \sum Y^{2}-\left(\sum Y\right)^{2}\right\}}}
$$


Volume 3, Nomor 1, Februari 2020

Adapun langkah-langkah yang digunakan adalah:

1. Membuat tabel perhitungan yang berisi tentang: $\mathrm{n}, \sum \mathrm{X}, \sum \mathrm{Y}, \sum \mathrm{X} 2, \sum \mathrm{Y} 2, \sum \mathrm{XY}$.

2. Mencari angka indeks " $r$ " Product Moment antara variabel $\mathrm{X}$ dan variabel $\mathrm{Y}$

3. Mengkonsultasikan nilai $r_{\text {hitung }}$ dengan $r_{\text {tabel }}$ pada taraf signifikan $5 \%$.

Dalam hal ini untuk memperoleh angka indeks korelasi " $r$ " product moment. Dengan mendistribusikan niali-nilai tersebut ke dalam korelasi " $r$ " Product Moment diperoleh hasil sebagai berikut:

$$
\begin{aligned}
& r_{x y}=\frac{n \sum X Y-\left(\sum X\right)\left(\sum Y\right)}{\sqrt{\left\{n \sum X^{2}-\left(\sum X\right)^{2}\right\}\left\{n \sum Y^{2}-\left(\sum Y\right)^{2}\right\}}} \\
& r_{x y}=\frac{35(158925)-(2155)(2545)}{\sqrt{\left\{35(136025)-(2155)^{2}\right\}\left\{35(188325)-(2545)^{2}\right\}}} \\
& r_{x y}=\frac{556237-5484475}{\sqrt{(476087-4644025)(6591375-6477025)}} \\
& r_{x y}=\frac{77900}{\sqrt{(116850)(114350)}} \\
& r_{x y}=\frac{77900}{115593,2416}=0,673
\end{aligned}
$$

Dari hasil penelitian di atas, maka diperoleh harga $r_{x y}=0,673$ yang maknanya terdapat hubungan positif yang tinggi atau kuat antara hasil belajar anak PAUD Amanah dengan diterapkan pendekatan realistik untuk mengenalkan atau mengajarkan matematika dasar pada anak PAUD.

Tabel 3: Makna nilai korelasi product moment

\begin{tabular}{|r|l|l|}
\hline \multicolumn{1}{|c|}{ N } & \multicolumn{1}{l|}{ Nilai } & Makna \\
\hline 1. & $0,00-0,19$ & Sangat rendah / Sangat lemah \\
\hline 2. & $0,20-0,39$ & Rendah / Lemah \\
\hline 3. & $0,40-0,59$ & Sedang \\
\hline 4. & $0,60-0,79$ & Tinggi / kuat \\
\hline 5. & $0,80-1$ & Sangat tinggi / Sangat kuat \\
\hline
\end{tabular}

Analisis korelasi digunakan untuk menjelaskan kekuatan dan arah hubungan antara dua variabel. Angka korelasi berkisar antara $-1 \mathrm{~s} / \mathrm{d}+1$. Semakin mendekati 1 maka korelasi 
semakin mendekati sempurna. Sementara nilai negative dan positif mengindikasikan arah hubungan. Arah hubungan yang positif menandakan bahwa pola hubungan searah atau semakin tinggi X menyebabkan kenaikan pula Y (X dan Y ditempatkan sebagai variabel)

Untuk mengetahui hipotesis tersebut diterima atau ditolak maka harga korelasi "r" Product moment tersebut kita konsultasikan ke dalam tabel harga kritik dari "r" Product Moment yang berada pada lampiran 10 sehingga rtabelpada $\mathrm{N}=35$ adalah 0,334 .

$$
\begin{aligned}
\mathrm{D} & =\mathrm{r} 2 \times 100 \% \\
& =(0,673) 2 \times 100 \% \\
& =0,452929 \times 100 \% \\
& =45,2929 \%
\end{aligned}
$$

Sehingga kontribusi yang diperoleh dari pendekatan realistik guru dengan hasil pemahaman matematika dasar pada pendidikan anak usia dini yaitu $45.29 \%$ dan $54,71 \%$ lagi dipengaruhi oleh faktor lain.

Untuk mengetahui taraf signifikannya maka dilakukan pegujian terhadap hipotesis yang ditegakkan dengan menggunakan uji t-tes, maka harga korelasi "r" Product moment tersebut dimasukkan ke dalam rumus uji t-tes, yaitu :

$$
\begin{aligned}
t_{\text {hitung }}= & \frac{r \sqrt{n-2}}{\sqrt{1-r^{2}}} \\
= & \frac{0,673 \sqrt{35-2}}{\sqrt{1-(0,673)^{2}}} \\
& 0,673 \times 5,74 \\
= & \frac{4}{\sqrt{1-0,453}} \\
= & \frac{3,866}{0,739} \\
= & 5,231
\end{aligned}
$$

Dari hasil di atas diperoleh $t_{\text {hitung }}=5,231$. Apabila dibandingkan dengan ttabel pada taraf kepercayaan 95\% atau tingkat kesalahan 5\% dengan derajat kebebasan $\mathrm{dk}=\mathrm{n}-2=35-$ $2=33$, tidak diperoleh di tabel maka dapat ditetapkan dengan rumus persamaan garis.

\begin{tabular}{|c|c|}
\hline $\mathbf{N}$ & $\mathbf{t}_{\text {tabel }}$ \\
\hline 30 & 1,70 \\
\hline 40 & 1,68 \\
\hline
\end{tabular}

$$
\begin{aligned}
& \frac{y-y_{1}}{y_{2}-y_{1}}=\frac{x-x_{1}}{x_{2}-x_{1}} \\
& \frac{33-30}{40-30}=\frac{x-1,70}{1,68-1,70} \\
& \frac{3}{10}=\frac{x-1,70}{-0,02}
\end{aligned}
$$




$$
\begin{aligned}
10 x & =17-0,06 \\
x & =\frac{16,94}{10} \\
& =1,694
\end{aligned}
$$

Sehingga $t_{\text {tabel }}$ adalah 1,694, apabila dibandingkan $t_{\text {hitung }}$ dengan $t_{\text {tabel }}$ terlihat bahwa $t_{\text {hitung }}$ lebih besar dibanding $t_{\text {tabel }}(5,231>1,694)$. Berdasarkan hasil konsultasi tersebut maka hipotesis alternatif yang dirumuskan dalam penelitian dapat diterima atau disetujui kebenarannya. Artinya terdapat Hubungan Hasil Belajar Matematika Dasar dengan menerapkan pendekatan realistik pada anak usia dini.

Setelah melakukan analisis data dan pengujian hipotesis,Hasil perhitungan diperoleh " $r$ " product moment adalah 0,673. Jika di interpretasikan terhadap tabel makna korelasi product momentdan analisis korelasi maka terdapat hubungan positif yang tinggi atau kuat antara hasil belajar dan pemahaman matematika dasar.

Sedangkan hasil pengujian hipotesisnya diperoleh nilai $t_{\text {hitung }}$ lebih besar dibanding $t_{\text {tabel }}$ $(5,231>1,694)$ yang artinya tolak $\mathrm{H}_{0}$ dan terima $\mathrm{H}_{1}$. Dimana $\mathrm{H}_{0}$ adalah tidak tedapat hubungan antara hasil belajar metematika anak paud pada materi matematika dasar.

\section{SIMPULAN}

Berdasarkan hasil penelitian serta perhitungan yang dilakukan maka penulis menarik kesimpulan yang didasarkan pada hasil analisis data sebagai berikut :

Hasil perhitungan diperoleh "r" product moment adalah 0,673. Jika di interpretasikan terhadap tabel makna korelasi product momentdan analisis korelasi maka terdapat hubungan positif yang tinggi atau kuat antara hasil belajar dan keterampilan variasi mengajar menggunakan pendekatan realistik pada anak usia dini.

Hasil uji hipotesis diperoleh $t_{\text {tabel }}$ 1,694 sedangkan $t_{\text {hitung }}$ sebesar 5,231 hal ini terlihat bahwa $t_{\text {hitung }}$ lebih besar dari $t_{\text {tabel }}(5,231>1,694)$. Artinya terdapat hubungan positif yang tinggi atau kuat antara pendekatan realistik dan pemahaman matematika dasar pada anak usia dini.

\section{UCAPAN TERIMA KASIH}

Pada artikel ini penulis mengucapkan terima kasih kepada Lurah Kampung Lapai berserta jajaran yang telah memberikan izin melakukan pengabdian masyarakat yang berada di PAUD Amanah. Selanjutnya kepada Kepada Sekolah PAUD Amanah Kampung Lapai dan guru-guru yang ikut serta dalam proses pengabdian masyarakat. Dan tidak lupa kepada anakanak PAUD Amanah Kampung Lapai. Terkhusus kepada pihak yang telah menerbitkan jurnal ini yaitu Jurnal Pengabdian Masyarakat Bakti Cendana Universitas Timor Nusa Tenggara Timur, Kupang.

\section{DAFTAR PUSTAKA}


Volume 3, Nomor 1, Februari 2020

[1] Arikunto, Suharsimi. 2010. Prosedur Penelitian. Rineka Cipta, Jakarta

[2] Arikunto, Suharsimi. 2007. Manajemen Penelitian. Rineka Cipta, Jakarta

[3] Damayanti, Ratna, Dwi dan Wahyuni. 2005. Program Pendidikan Anak Usia Dini di Prasekolah Islam. Jakarta: Gramedia Widiasarana Indonesia

[4] Harlan.2008. Matematika untuk PAUD. (http:www.Matematika PAUD.co.id, diakses 25 November 2019

[5] Howard, Gardner.1999. Multiple Intelligences. Terjemahkan oleh Moch Hanafi.2000.Bandung:Remaja Rosdakarya

[6] Mujib dan Mudjakir.2001.Tumbuh Kembang Anak. Surabaya:Remaja Rosdakarya

[7] Sugiyono. 2007. Metode Penelitian Sains. Alfabeta, Bandung 